\title{
Review Article: Economic evaluation of flood damage to agriculture - review and analysis of existing methods
}

\author{
P. Brémond ${ }^{1}$, F. Grelot ${ }^{1}$, and A.-L. Agenais ${ }^{1}$ \\ ${ }^{1}$ IRSTEA, UMR G-EAU, Montpellier, France \\ Correspondence to: P. Brémond (pauline.bremond@irstea.fr) \\ Received: 7 December 2012 - Published in Nat. Hazards Earth Syst. Sci. Discuss.: - \\ Revised: 10 July 2013 - Accepted: 22 July 2013 - Published: 9 October 2013
}

\begin{abstract}
In Europe, economic evaluation of flood management projects is increasingly used to help decision making. At the same time, the management of flood risk is shifting towards new concepts such as giving more room to water by restoring floodplains. Agricultural areas are particularly targeted by projects following those concepts since they are frequently located in floodplain areas and since the potential damage to such areas is expected to be lower than to cities or industries for example. Additional or avoided damage to agriculture may have a major influence on decisions concerning these projects and the economic evaluation of flood damage to agriculture is thus an issue that needs to be tackled.

The question of flood damage to agriculture can be addressed in different ways. This paper reviews and analyzes existing studies which have developed or used damage functions for agriculture in the framework of an economic appraisal of flood management projects. A conceptual framework of damage categories is proposed for the agricultural sector. The damage categories were used to structure the review. Then, a total of 42 studies are described, with a detailed review of 26 of them, based on the following criteria: types of damage considered, the influential flood parameters chosen, and monetized damage indicators used.

The main recommendations resulting from this review are that even if existing methods have already focused on damage to crops, still some improvement is needed for crop damage functions. There is also a need to develop damage functions for other agricultural damage categories, including farm buildings and their contents. Finally, to cover all possible agricultural damage, and in particular loss of activity, a farm scale approach needs to be used.
\end{abstract}

\section{Introduction}

In Europe, a new orientation is given to the management of flood risk, which consists of giving more room to water by restoring floodplains or creating retention areas, and which may also require assets to be adapted to flood risk (Johnson et al., 2007b). Flood risk management including floodplain restoration actions implies that, to protect vulnerable (generally urban) areas, less vulnerable (generally agricultural) land will be more exposed to flooding (Posthumus et al., 2009; Erdlenbruch et al., 2009).

In the meanwhile, flood risk management projects are usually economically evaluated by Cost-Benefit Analysis (CBA) and require accurate hydraulic models to evaluate hydraulic consequences in terms of the depth, duration and velocity of the water, and, on the other hand, accurate damage models able to quantify the vulnerability of the different land uses affected in order to estimate the socio-economic consequences of flooding. To perform CBA, different economic sectors are usually distinguished and associated with damage functions (Penning-Rowsell et al., 2005). Among these sectors, agriculture is frequently considered to be of minor importance compared to industrial or residential sectors, for example, because at the same level of exposure, total damage may be comparatively lower (Merz et al., 2010). However, for projects including floodplain restoration, evaluating potential agricultural damage is indispensable to assess implications for more exposed areas, and so to determine economic efficiency of the projects. This may become crucial if projects consist in modifying existing protections, which allowed development of high value crops (horticulture, orchard, for example). 
The aims of this article are to identify existing methods for evaluating potential agricultural damage from an economic point of view and to determine if the methods are suitable for the evaluation of flood risk management projects. We focus on the review of methods to evaluate potential agricultural damage, when both flood hazard and land use (i.e. specification of the characteristics of agricultural land use) are stated. The emphasis is placed on flood due to rivers, but some insights are useful for coastal inundations (implication of salinity).

To undertake a complete evaluation of flood risk management projects, it is essential to know the current land use and how the project could affect it. In agriculture, land use is highly dependent on flood frequency. Generally, the main crops cultivated and farmers' practices are adapted to a given flood frequency. For instance, Roca et al. (2011) have shown that in England and Wales, high value crops (horticulture) are comparatively less present in frequently flooded areas than other crops (grass, cereals). A change in flood frequency can have long term consequences for both the main types of crops grown and for farmers' practices and both need to be considered for economic evaluation. In this article, we do not discuss on this important topic of farms adaptation caused by changes in flood frequency. For a detailed method on this topic, see Penning-Rowsell et al. (2005, p. 192-198).

We also want to alert that, covering all the impacts of floodplain restoration is very complex because of the entangled issues of food security (Morris, 1992; Posthumus et al., 2010), biodiversity (Rouquette et al., 2009) and equity of damage distribution (Johnson et al., 2007a). We focus only on methods to assess economic damage to agriculture. But the issue of flood damage to agriculture could also be tackled from other perspectives not considered here: an ex-post description of the damage due to a specific flooding event (Twining et al., 2007; Chatterton et al., 2010; Posthumus et al., 2009; Morris and Brewin, 2013), defining financial damage for farmers (Posthumus et al., 2009; Morris and Brewin, 2013), and determining compensation in the case of floodplain restoration (Erdlenbruch et al., 2009; Beedell et al., 2012).

In terms of economic evaluation, the shift towards new policies requires checking if existing methods to evaluate agricultural damage are suitable. As pointed out by Posthumus et al. (2009), there is a clear need to ensure that the characteristics of agricultural activities that make them particularly vulnerable are accurately considered in the methods concerned. To this end, in this article we:

- build a conceptual framework of damage categories for agricultural assets which enables us to compare all the studies reviewed (Sect. 2);

- review existing methods of assessing flood damage to agriculture (Sect. 3);
- analyze their suitability for the evaluation of flood management projects (Sect. 4);

- identify future research needs and make recommendations for future methodological developments (Sect. 5).

Our aim is to analyze and compare existing methods from a conceptual point of view, mainly which damage categories and which flood parameters are considered in damage functions. Comparing the amount of damage was not possible since the figures provided in the studies reviewed are very context specific.

\section{Conceptual framework}

Before reviewing methods to evaluate economic damage to agriculture, based on ex-post studies, we propose a framework to analyze the different categories which should be included in the economic evaluation methods.

\subsection{Flood damage classification}

Although in the literature, the terms "impact", "damage", and "cost" are often used interchangeably, we make a clear distinction between the three. In this article, we consider that flood impacts are any effects flood may have on the system concerned; damage refers to a negative impact; and cost is the evaluation of damage in monetized terms. "System" refers to a set of components, linked together through relationships of interaction and dependence. For example, a farm can be considered as a system composed of material components (plots, buildings, etc.) and immaterial components (finance, knowlegde, etc.), linked together through an organization. We also use the term "loss" to designate damage that results in the decreasing or the disappearance of some component of the system.

A typology of the costs due to natural hazards including flooding was recently established by the research consortium CONHAZ (Meyer et al., 2012). The typology first distinguishes between tangible and intangible damage. Tangible damage is defined as a negative impact that can be easily quantified. Conversely, the quantification of intangible damage, i.e. environmental damage such as loss of biodiversity or aesthetic impacts; and health damage such as injuries, stress and anxiety is considered to be not easy or even impossible to measure. Thus, intangible damages are very often not taken into account in the monetary evaluation of damage (Lekuthai and Vongvisessomjai, 2001). According to the CONHAZ consortium, costs of intangible damage cannot be evaluated by market based approaches. The studies reviewed in Sect. 3 only include tangible damage. For a review of economic valuation methods concerning intangible damage of natural hazard, see Markantonis et al. (2012).

Second, the typology distinguishes between direct and indirect damage. This distinction is commonly accepted as a 
spatial distinction. Direct damage corresponds to damage limited to the flooded area and indirect damage corresponds to what occurs outside the flooded area (Jonkman et al., 2008). There may be confusion when the term indirect damage is also used for damage that occurs within the flooded area but later in time. To avoid this confusion, we propose a third distinction by using the words instantaneous and induced damage to create a temporal distinction.

To summarize, based on the recommendation of Merz et al. (2010), we propose to distinguish different tangible damage categories depending on their spatial and temporal scales. Concerning the temporal scale, we distinguish:

- instantaneous damage, which occurs during or immediately after the flood event;

- induced damage, which occurs later in time.

Naturally, in practice, the distinction between instantaneous and induced damage is not that clear and depends on the time scale chosen to analyze the system. In the case of agriculture, we consider that instantaneous damage is damage can be observed just after flooding and induced damage is damage that occurs later, i.e. up to the end of the current cropping season and in the years that follow. Concerning the spatial scale, we distinguish:

- direct damage, which is related to direct exposure to flooding;

- indirect damage, which occurs in a area that has not been exposed to flooding.

This distinction depends to a great extent on the boundaries of the system under study. In the case of agriculture, different boundaries can be chosen (the plot, the farm, the agricultural sector) that will influence the qualification of direct and indirect damage. Thereafter, four damage categories of tangible damage are distinguished:

- direct instantaneous damage;

- direct induced damage;

- indirect instantaneous damage;

- indirect induced damage.

Due to the unclear boundaries between these damage categories, damage is not always cited in this way in studies we review here, but we decided to reorganize and analyze the different categories of agricultural flood damage according to this system of classification.

\subsection{Categories of flood damage to agriculture}

To illustrate each category of flood damage, examples concerning agriculture are given in Table 1 . To cover as many different instances of damage as possible, we chose the farm scale. This implies that direct damage refers to damage to farm components and indirect damage refers to damage to other economic activities (other farms, suppliers, retailers for example) that were not directly impacted by the flood, but which have business relations with farms that were impacted.

\subsubsection{Direct instantaneous damage}

Different farm components can be impacted by a flood. Some components correspond to flows (crops, stocks), other to assets (perennial plant material, farm buildings, machinery). Based on ex-post qualitative studies of flood impacts on agriculture (Pivot et al., 2002; Neubert and Thiel, 2004; Bauduceau, 2001; Chatterton et al., 2010; Bauduceau, 2004a; Twining et al., 2007; Posthumus et al., 2009; Morris and Brewin, 2013), seven subcategories of direct instantaneous damage are distinguished:

- crop loss and yield reduction;

- damage to or destruction of the perennial plant material (vineyards, orchards);

- fatalities and injuries to livestock;

- loss of livestock products (milk, eggs);

- damage to soil (erosion, debris and litter deposit, contamination);

- damage to buildings;

- damage to machinery and equipment;

- damage to stored materials (inputs, feed and fodder).

Damage to infrastructure such as roads and paths, is rarely specifically mentioned in connection with agricultural areas but is reported by Bauduceau (2001), Chatterton et al. (2010), Morris and Brewin (2013).

Some of these ex-post studies (Bauduceau, 2004a; Posthumus et al., 2009; Morris and Brewin, 2013) mention that the reduction in yield may cause some variations in production costs: savings due to a decrease in yield (e.g. reduction in the time dedicated to some tasks). These savings occur after the flood and may continue until the end of the production cycle. However, as they can be anticipated depending on the loss of yield, they are usually taken into consideration to calculate direct damage to crops.

\subsubsection{Direct induced damage}

Direct induced damage to agriculture that can be considered depend on the scale at which agricultural activities are studied. When agriculture is studied only through land use (i.e. parcels and farm buildings separately), little direct induced damage can be taken into account. Bauduceau (2001) points to future loss of yield that would continue for a number of years after flooding when perennial plant material is 
Table 1. Classification of flood damage to agriculture

\begin{tabular}{|c|c|c|}
\hline & Instantaneous (just after flooding) & Induced (later after flooding) \\
\hline Direct (due to flood exposure) & $\begin{array}{l}\text { - crop loss and yield reduction } \\
\text { - livestock fatalities } \\
\text { - loss of livestock products (e.g. milk) } \\
\text { - damage to perennial plant material } \\
\text { - damage to soil } \\
\text { - damage to buildings } \\
\text { - damage to machinery } \\
\text { - damage to stored inputs } \\
\text { - damage to infrastructure (e.g. roads) }\end{array}$ & $\begin{array}{l}\text { - loss of added value due to the loss of } \\
\text { yield in the first years after replanting } \\
\text { perennial plant material (orchard, vine- } \\
\text { yard) or reseeding grass } \\
\text { - loss of added value due to unavailability } \\
\text { of production factors (machinery, inputs } \\
\text { etc.) } \\
\text { - cost of relocation or premature sales of } \\
\text { livestock } \\
\text { - cost of additional food for livestock } \\
\text { - reduction of herd size }\end{array}$ \\
\hline $\begin{array}{l}\text { Indirect (not directly due to } \\
\text { flood exposure) }\end{array}$ & $\begin{array}{l}\text { - increase in travel time due to damage to } \\
\text { infrastructure } \\
\text { - delay or cancellation of supply from the } \\
\text { flooded area (inputs, machinery, etc.) }\end{array}$ & $\begin{array}{l}\text { - loss of added value outside the flooded } \\
\text { area due to business interruption of as- } \\
\text { sets in the flooded area } \\
\text { - loss of added value outside the flooded } \\
\text { area due to damage to infrastructure }\end{array}$ \\
\hline
\end{tabular}

destroyed. Specifically with respect to livestock, Posthumus et al. (2009) mention direct induced damage such as reduced milk production, due to loss of grass yield and feed value, or an increase in costs of veterinary treatment due to the consequences of stress for animals. Bauduceau (2001) also mentions possible increases in production costs (e.g. additional inputs to limit losses). When some direct damage is not entirely repaired (soil erosion, soil contamination, for example), it may also lead to restrictions in land use, for instance in disallowing certain crops.

Lastly, the execution of some tasks can modify initial damage. Including the impacts of those action in a damage framework is not straightforward, and implies some more analysis. For example, livestock evacuation can reduce fatalities and injuries to animals, in case of sufficiently early warnings, anticipated harvest could also be considered to reduce loss of yield (although it is not mentionned in the litterature); reseeding the same crop (or sowing a new crop depending on the farm calendar) is supposed to reduce loss of added value at farm level: the original crop would be completely lost but a new substitute crop would be obtained. Inluding these actions imply including savings or new income expected but also new expenses generated, which have to be assessed.

When farms are studied as a whole entity (i.e. considering links between land parcels, buildings, machinery), empirical studies point to some disturbance in farm activity due to the flood event. For example, a multi-criteria analysis of farm vulnerability to flooding (Barbut et al., 2004) based on empirical work carried out by Bauduceau (2004b), shows that one of the criteria that best explains vulnerability is the overwhelming increase in work involved in recovery tasks. Pivot et al. (2002) also highlight the fact that beyond direct damage to elementary components, damage at the scale of the farm may differ depending on farm internal organisation, the availability of production resources, and farm decision making. Posthumus et al. (2009) and Morris and Brewin (2013) confirm that, at farm scale, flooding can lead to a delay in harvesting or in other field operations in unflooded plots if machinery is not available or if there are too many tasks to do at the same time. Moreover, these authors mention that the impacts of flooding may continue for on several years by changing crop rotation. For instance, due to the impossibility of preparing the soil, it may be also impossible to sow the next crop in time.

\subsubsection{Indirect damage}

To encompass indirect damage, the scale to be considered needs to be larger than the farm scale, i.e. a regional or national scale.

Some qualitative studies mention possible impacts of flooding on agricultural activities that do not actually take place in the flood plain area (Bauduceau, 2004b; Brémond et al., 2008). For instance, farmers who are not directly impacted may suffer disruption in their supply of inputs (including stored fodder) if these activities have been impacted. Closely related economic sectors may also be disrupted even 
if they are not directly impacted by the flood: if harvests have been destroyed, the food industry may suffer from a shortage depending on their capacity to find substitutes to lost harverst on markets; if a lot of farms go to bankruptcy, the food industry may have to reorganized to adapt to this new situation.

Concerning indirect damage, the distinction between instantaneous and induced damage is not so easy. It depends on the dynamic of propagation of impacts in the society, it also requires taking capacity to find substitutes into account at a macroscopic level, which is beyond the scope of this paper.

\section{Review of methods}

Forty-two studies which use or aim to develop damage functions to evaluate ex-ante damage to agriculture due to flooding were reviewed and are listed in table 2. Several types of hazards can be grouped together under the word "flood", e.g. inundation by submersion, water logging due to bad drainage conditions, inundation by salt water due to coastal flooding. Our focus is on inundation by submersion, i.e. aboveground flooding. Some studies first focused on water logging before adapting the method to inundation by submersion or dealt jointly with the two hazards (Morris and Hess, 1988; Poirée and Ollier, 1973).

\subsection{The review process}

\subsubsection{Search procedure}

To collect studies on the subject, four methods were used:

1. Keyword searches: "Damage" AND ("Flood" OR "Flooding") AND ("Agriculture" OR "Rural" OR "Agricultural") using search engines including Scopus, Web of Science and Google Scholar. This search was conducted regularly and results were checked over a period of $5 \mathrm{yr}$.

2. References specifically related to flood damage to agriculture were extracted from existing reviews (Meyer and Messner, 2005) and guidelines (Penning-Rowsell et al., 2005).

3. Grey literature was collected during projects for the implementation of floodplain restoration (Brémond et al., 2007) and the creation of flood retention areas (Brémond et al., 2007) in France by the authors' research team.

4. Personal communications enabled us to review specific studies such as the Japanese guidelines for economic appraisal of flood control projects (MLIT, 2005).

Although our review was intended to be exhaustive, language proved to be an obstacle and local literature not cited in an English or French document may have escaped out attention.

\subsubsection{Selection of studies and analytical criteria}

The studies listed in Table 2 do not each present a completely different methodology. Generally, studies in the same country are clearly linked and report the development of a methodology by a group of researchers or experts. The relations between studies are presented in Sect. 3.2.

To perform our detailed analysis, we then selected studies which significantly differed from the others and which proposed or used quantitative damage functions. These are the 26 studies in bold in Table 2. Thereafter in Sect. 3.3, these 26 studies are analyzed in more detail based on the following criteria:

- the damage categories considered (Sect. 3.3);

- the hazard parameters used in damage functions (Sect. 3.4);

- the economic indicators used to monetize damage for each component (Sect. 3.5).

\subsubsection{Focus on damage to agriculture}

Not all the studies listed in Table 2, give the same importance to the method used to evaluate flood damage to agriculture. In the column headed "Focus" in Table 2, three levels are distinguished:

1. Studies whose aim is to develop a methodology to evaluate ex-ante damage to agriculture (listed under Methodology) and which can be used in several contexts;

2. Studies in which some local damage functions have been developed for agriculture (listed under Local Damage Functions);

3. Studies which use existing agricultural damage functions (listed under Application) and which usually provide a few details on the origins of the damage functions used.

\subsubsection{Link to ex-post analysis}

Although the selected studies aim at produce damage functions to assess ex-ante evaluation of flood damage, most of them were based on ex-post analysis of past events. This link varies between studies, and is not always explicitly mentionned. Ex-post analysis may be used to precise some mechanisms explaining damage, or to estimate, based on expert knowledge, some costs or others figures needed to assess loss. Förster et al. (2008) was based on the construction of empirical damage function from a database of damage given by insurance companies (HOWAS). Poirée and Ollier (1973) 
and Duthion (1982) make reference to experiments made explicitly to assess crop loss due to flood.

\subsection{General overview of all the studies}

In this subsection, we provide a brief explanation on the 42 studies we identified on the subject. We have chosen to make this presentation, by grouping studies coming from the same country, because this is a way to show how those studies are linked together or not.

In the United Kingdom, the model, SCADE (Silsoe College Agricultural Drainage Evaluation Model) was developed to evaluate agricultural damage. It is the result of an integrated approach based on observation and supported by experimental research. Due to the specific importance of drainage in the climatic context of the UK, assessment of flood damage and damage due to excess water in the soil are coupled. The method has been applied and adapted to several case studies in the UK (Morris and Hess, 1988; Hess and Morris, 1988; Dunderdale and Morris, 1997a, b; Morris et al., 2000, 2008, 2004). Subsequent improvements were associated with methodological research on flood damage assessment carried out by the FHRC (Flood Hazard Research Centre) and supported by the Department of Environment, Food and Rural Affairs (DEFRA), formerly Ministry of Agriculture, Fisheries and Food (MAFF). Finally, this joint research effort resulted in the publication of a set of guidelines for economic assessment of flood risk management projects (Penning-Rowsell and Chatterton, 1977; Parker et al., 1987; Penning-Rowsell et al., 1992, 2005; Riddel and Green, 1999).

In Germany, the work carried out by Förster et al. (2008) to assess the efficiency of a rural retention project was part of a wider project named MEDIS (Methods for the Evaluation of the Direct and Indirect Flood Losses). This project ran from 2005 to 2008 and aimed at improving approaches for flood loss estimation (Thieken et al., 2008). It involved researchers from several German research institutes. Using damage model developped within MEDIS project, Tapia-Silva et al. (2011) compared three different methods to predict flood-affected crops for estimating crop loss. Two further damage models, the ICPR model, which was mainly developed in Germany, and the Dutch damage scanner, which among many other sectors also (partly) consider losses in the agricultural sector, are quickly presented and compared in Bubeck et al. (2011).

In France, some of the studies were conducted by agricultural technical institutes to represent the interest of farmers, for instance in the implementation of flood risk management projects. In Burgundy Region, the regional agricultural institute developed a method based on the compilation and adaptation of previous studies (Pierson et al., 1994). This method was then applied and completed on a smaller scale in the Saône-et-Loire French Department (Dury and Didier, 2006). The institute in charge of the implementation of the Loire River water management plan developed another method (Devaux-Ros, 2000) which was then adapted for the Rhône River area (SIEE et al., 2003). More recently, a method was proposed by agricultural experts in the Gard Department (CA30, 2009), whose aim was to include additional damage categories and to describe the damage in detail. Some studies were conducted in other French areas such as Citeau (2003) or Bournot (2008) but were not sufficiently documented to be included in the detailed review. The studies conducted on the Loire, the Rhône and the Saône-et-Loire rivers are very context specific. But they have some reciprocal influences on studies conducted by applied research institutes.

Studies performed by research institutes have the overall aim of improving methods of flood damage assessment (Deleuze et al., 1991; Torterotot, 1993; Erdlenbruch et al., 2007; Blanc, 2008; Blanc et al., 2008, 2010; Agenais, 2010; Brémond, 2011). Studies by Blanc et al. (2010) and Brémond (2011) were specifically dedicated to the development of a method to assess flood damage to agriculture. A study by Agenais (2010) was dedicated to the development of a method to assess damage to agriculture caused by saline flood water within the framework of a wider research project on marine submersion due to a rise in sea level in the Languedoc-Roussillon Region. In some of these studies, results of some quite old agronomic experiments (Poirée and Ollier, 1973; Duthion, 1982) were used as references to construct crop damage functions since no more recent experiments have been conducted.

In France, an atypical approach was developed called the "Inondabilité"1 Method (Gilard, 1998). It enables a maximum acceptable risk to be defined for each type of land use in order to identify high and low risk areas and optimize flood distribution within a given territory. Based on expert knowledge, land use vulnerability is defined as the return period and hazard parameters beyond which the hazard is qualified as unacceptable. Although this method has produced vulnerability indicators for some agricultural land use, it is not appropriate for damage assessment because no economic indicators are proposed.

In the USA, research on damage to agriculture by floods and excess water has been long carried out notably by Lacewell and Eidman $(1970,1972)$ and and the US Army Corps of Engineers (USACE, 1985). One application in the USA was also made by McDonald (1970). Specific attention was paid to agricultural damage since floodplain restoration was under discussion in the USA before Europe. AGDAM (Agriculture Flood Damage Analysis) is a methodology developed by the US Army Corps of Engineers (USACE, 1985). This methodology is part of a wider software, HECFDA (Hydrologic Engineering Center - Flood Damage Analysis) which aims at evaluating flood management projects.

\footnotetext{
1"Inondabilité" is a neologism expressing the acceptability of being flooded.
} 
Table 2. Main characteristics of studies dealing with flood damage functions to agriculture (references highlighted in bold are analysed in detail).

\begin{tabular}{|c|c|c|c|c|c|}
\hline Author & Country & Year & Application & Focus & Language \\
\hline Agenais (2010) & France & 2010 & Languedoc-Roussillon & Methodology & French \\
\hline Blanc et al. (2008) & France & 2008 & Touloubre & Local Damage Functions & French \\
\hline Blanc (2008) & France & 2008 & Touloubre & Local Damage Functions & French \\
\hline Bubeck et al. (2011) & Germany & 2008 & Rhine River & Application & English \\
\hline Brémond and Grelot (2010) & France & 2010 & Rhône & Methodology & French \\
\hline Brémond (2011) & France & 2011 & Rhône & Methodology & English \\
\hline CA30 (2009) & France & 2009 & Rhône & Methodology & French \\
\hline Consuegra Zammit (1992) & Switzerland & 1992 & Broye & Local Damage Functions & French \\
\hline Deleuze et al. (1991) & France & 1991 & - & Methodology & French \\
\hline Devaux-Ros (2000) & France & 2000 & Loire Moyenne & Methodology & French \\
\hline Dunderdale and Morris (1997a) & UK & 1997 & River Wensum & Local Damage Functions & English \\
\hline Dunderdale and Morris (1997b) & UK & 1997 & River Wensum & Local Damage Functions & English \\
\hline Du Plessis and Viljoen (1997) & South Africa & 1997 & - & Methodology & Afrikaans \\
\hline Du Plessis and Viljoen (1998) & South Africa & 1998 & Orange river area & Local Damage Functions & English \\
\hline Du Plessis and Viljoen (1999) & South Africa & 1999 & Orange river area & Methodology & English \\
\hline Dury and Didier (2006) & France & 2006 & Saône-et-Loire & Methodology & French \\
\hline Dutta et al. (2003) & Japan & 2003 & Ichinomiya & Local Damage Functions & English \\
\hline Erdlenbruch et al. (2007) & France & 2007 & Orb & Local Damage Functions & French \\
\hline Duthion (1982) & France & 1982 & - & Methodology & French \\
\hline Förster et al. (2008) & Germany & 2008 & Elbe & Local Damage Functions & English \\
\hline Gayler et al. (2001) & Australia & 2001 & - & Methodology & English \\
\hline Goulter and Morgan (1983) & Canada & 1983 & Wilson Creek, Manitoba & Application & English \\
\hline Hess and Morris (1988) & UK & 1988 & South West England & Methodology & English \\
\hline Hoes and Schuurmans (2006) & Netherland & 2006 & Westeramstel area & Application & English \\
\hline Jonkman et al. (2008) & Netherland & 2008 & Souh Holland & Application & English \\
\hline Lacewell and Eidman (1970) & USA & 1970 & - & Local Damage Functions & English \\
\hline Lacewell and Eidman (1972) & USA & 1972 & Nuyaka Creek floodplain & Local Damage Functions & English \\
\hline Lacewell et al. (2006) & USA & 2006 & Willacy County, Texas & Methodology & English \\
\hline McDonald (1970) & USA & 1970 & gladstone -Kinchela & Application & English \\
\hline MLIT (2005) & Japan & 2005 & - & Methodology & Japanese \\
\hline Morris and Hess (1988) & UK & 1988 & South West England & Methodology & English \\
\hline Morris et al. (2000) & UK & 2000 & East England & Local Damage Functions & English \\
\hline Morris et al. (2008) & UK & 2004 & England & Local Damage Functions & English \\
\hline Morris et al. (2004) & UK & 2004 & England & Local Damage Functions & English \\
\hline Penning-Rowsell et al. (2005) & UK & 2005 & - & Methodology & English \\
\hline Pierson et al. (1994) & France & 1994 & - & Methodology & French \\
\hline Poirée and Ollier (1973) & Hungary & 1948 & - & Methodology & French \\
\hline Satrapa et al. (2012) & Czech republic & 2012 & - & Local Damage Functions & Czech \\
\hline SIEE et al. (2003) & France & 2003 & Rhône & Methodology & French \\
\hline Tapia-Silva et al. (2011) & Germany & 2008 & Havel River & Application & English \\
\hline Torterotot (1993) & France & 1991 & Orb & Local Damage Functions & French \\
\hline USACE (1985) & USA & 1985 & - & Methodology & English \\
\hline
\end{tabular}

In Japan, a national guide for economic appraisal of flood control projects (MLIT, 2005) has been used in a case study by Dutta et al. (2003). In Australia, a national guide also exists (Gayler et al., 2001) but no applications in a real case study were found.

In South Africa, Du Plessis, Viljoen and Berning (1997; 2000) developed a specific module for agriculture within in a wider flood damage simulation model (FLODSIM). Damage functions were built for several crops and the method was applied to a real case study (Du Plessis and Viljoen, 1998).

In the Netherlands, Hoes and Schuurmans (2006) and Jonkman et al. (2008) presented results of an economic assessment of flood management projects and of the use of damage functions for agriculture, but no methodological details were provided and no national recommendations in English were found. 
According to Meyer and Messner (2005), Satrapa and Horsky are Czech researchers who are experts in flood damage modelling and some damage functions that they developed for agriculture are presented in some reports (Satrapa et al., 2012).

Some more isolated studies were also analyzed. Goulter and Morgan (1983) evaluated flood management in a rural area in Canada. But little attention was paid to the method used to appraise agricultural damage. In Switzerland, Consuegra Zammit (1992) analyzed flood management projects in a framework closely resembling the Inondability method. In the application to the Broye watershed, this author details the method used to assess damage to agriculture and specifically tackles the question of seasonality and crop rotation.

\subsection{Damage categories considered}

In this section, we review the 26 studies in bold in Table 2, analyzing the damage categories considered. All these studies aim at quantifying direct damage to agriculture, according to the classification we propose in Sect. 2.2. One study (Du Plessis and Viljoen, 1999) focuses on indirect damage and is presented in Sect. 3.3.3.

\subsubsection{Direct instantaneous damage}

Table 3 lists the category of damage taken into account in each of the 26 papers reviewed in detail. The farm components considered are crop, livestock, farm buildings, machinery, soil, stock, and plant material (see list in Sect. 2.2.1. Details are provided in the following paragraphs.

The first column in Table 3 shows that all the studies include damage to crops. A more detailed analysis shows that only 19 mention several different types of crops. Among these 19 studies, CA30 (2009), Agenais (2010) and Consuegra Zammit (1992) even consider the fact that the type of crop in a plot may change, as in a crop rotation. In Erdlenbruch et al. (2007) and McDonald (1970), the question is simplified to two types of crops. Morris and Hess (1988) focus on pasture and Duthion (1982) on maize. However, in Hoes and Schuurmans (2006) and Jonkman et al. (2008), the crop type corresponding to the damage function used in the study is not specified. In USACE (1985), which is more a methodological approach, no crop damage functions are directly given. We discuss the indicators used to assess crop damage in Sect. 3.5.1.

As can be seen in column 2 in Table 3, two studies address the issue of evaluating damage to livestock: DevauxRos (2000) and Morris and Hess (1988). Devaux-Ros (2000) proposes a method to evaluate the cost of fatalities and loss of livestock production due to flooding. In the case study in which Morris and Hess' (1988) method was applied, no livestock fatalities occurred. As a consequence, the method to appraise damage related to livestock fatalities is not discussed in the article. However, the authors include an increase in feeding costs due to the decrease in the nutritional quality of pasture. In our framework, this damage is classified as an induced damage (see Sect. 3.3.2).

An important category is damage to farm buildings and their contents (column 4 in Table 3). By buildings, we mean here agricultural buildings (commercial buildings) where machinery and inputs are stored (sheds and/or greenhouses) and not farm houses residential buildings. Nine methods include damage to agricultural buildings. But, among them, some do not really propose or use specific damage functions for commercial buildings but instead use damage functions developed for residential buildings (Blanc et al., 2008; Erdlenbruch et al., 2007). Only four methods, Brémond (2011), Dutta et al. (2003), SIEE et al. (2003) and DevauxRos (2000) explicitly propose damage functions for agricultural buildings specifically adjusted to farm activity. Moreover, in SIEE et al. (2003) and Devaux-Ros (2000), damage to buildings includes damage to machinery. Several damage functions for agricultural buildings are defined depending on crop specialization. Two other studies define damage to machinery separately from damage to buildings: CA30 (2009) and Brémond (2011). These are also the only two studies proposing damage functions for stocks stored in buildings.

Four studies propose a method to evaluate damage to the soil of the plots concerned (column 5 in Table 3 ). This mainly includes the cost of restoration in the case of soil erosion and of removing deposits from the soil.

Depending on the crops studied, damage to plant material may be important. This type of damage concerns perennial trees or plants such as vineyards, orchards or sugar cane. Some damage functions have been developed for the French Mediterranean region (SIEE et al., 2003; CA30, 2009; Agenais, 2010; Brémond, 2011) or on the Loire River (DevauxRos, 2000) and in South Africa (Du Plessis and Viljoen, 1997). Direct damage to plant material can be evaluated separately but is usually combined with the evaluation of induced damage, i.e. loss of income for several years until the orchard or vineyard reaches its previous level of productivity (see Sect. 3.3.2).

\subsubsection{Direct induced damage}

As mentioned in Sect. 2.2.2, most induced damage can be defined only if the study is conducted at farm scale. A farm can be subject to disturbance or disruption of its activity due to the flood, just like other economic sectors. In the studies we reviewed, the farm scale is rarely considered and, as a consequence, induced damage to farm functioning is rarely taken into account although ex-post studies, mentioned in Sect. 2.2.2 (Bauduceau, 2001; Pivot et al., 2002; Posthumus et al., 2009) do.

Morris and Hess (1988) developed a method to assess induced damage specific to grassland farming, which is employed in Penning-Rowsell et al. (2005). This method proposes a comprehensive model of the relation between flooded 
Table 3. Farm components taken into account for the evaluation of direct damage in the studies reviewed.

\begin{tabular}{|c|c|c|c|c|c|c|c|c|}
\hline Author & Crop & Crop Type & Livestock & Building & Machinery & Soil & Stock & Plant Material \\
\hline Blanc et al. (2008) & yes & several & - & yes & - & - & - & - \\
\hline CA30 (2009) & yes & several & - & - & yes & yes & yes & yes \\
\hline Consuegra Zammit (1992) & yes & several & - & - & - & - & - & - \\
\hline Deleuze et al. (1991) & yes & several & - & - & - & - & - & - \\
\hline Du Plessis and Viljoen (1997) & yes & several & - & yes & - & yes & - & yes \\
\hline Duthion (1982) & yes & corn & - & - & - & - & - & - \\
\hline Dutta et al. (2003) & yes & several & - & yes & yes & - & - & - \\
\hline Erdlenbruch et al. (2007) & yes & simplified (2 types) & - & yes & - & - & - & - \\
\hline Förster et al. (2008) & yes & simplified (2 types) & - & - & - & - & - & - \\
\hline Lacewell et al. (2006) & yes & several & - & - & - & - & - & - \\
\hline McDonald (1970) & yes & simplified (2 types) & - & - & - & - & - & - \\
\hline Morris and Hess (1988) & yes & pasture & yes & - & - & - & - & - \\
\hline Penning-Rowsell et al. (2005) & yes & several & yes & yes & - & - & - & - \\
\hline Pierson et al. (1994) & yes & several & - & - & - & - & - & - \\
\hline Poirée and Ollier (1973) & yes & several & - & - & - & - & - & - \\
\hline Satrapa et al. (2012) & yes & several & - & - & - & - & - & - \\
\hline SIEE et al. (2003) & yes & several & - & yes & yes & - & - & yes \\
\hline USACE (1985) & yes & - & - & - & - & - & - & - \\
\hline
\end{tabular}

pastures and the consequences for livestock growth. The damage to agricultural products is assessed through the additive costs required to continue feeding and housing livestock due to damage to grassland and buildings. Pierson et al. (1994) also mention induced damage, but do not propose functions to assess them. Some induced impacts considered in those studies are:

- additional food for livestock;

- relocation of livestock;

- cost of securing water for livestock if potable water supplies are disrupted;

- reduction in sales due to the impossibility of transporting livestock;

- premature sales or reduced numbers of livestock and livestock products.

Concerning crops, Lacewell et al. (2006) updated the method they originally developed in 1972 by including the increase in production costs induced by flooding such as additive phytosanitary treatments or additive field operations. Those additive costs were defined based on interviews with farmers for several crop types.
Brémond (2011) developed a method to evaluate induced damage to farm activity due to the increase in workforce required for recovery (cleaning, repairing, etc.) as well as damage to machinery. This method considers the baseline organization without flooding and subsequent reorganization after a flood event. The possibility to access external resources is also taken into account to evaluate induced damage to activity. For further details on this method, see Brémond and Grelot (2012). This study required a highly detailed farm scale analysis to assess the length of time before farm functioning was back to normal and to estimate the potential incompatibility and priority between repair tasks and agricultural tasks depending on the farmer's access to external resources (workforce, machinery, cash).

\subsubsection{Indirect damage}

As mentioned in Sect. 2.2.3, very few studies described indirect damage and even fewer assess it. Du Plessis and Viljoen (1999) calculated the indirect impacts of floods in the lower Orange River area at regional and national scales. Du Plessis and Viljoen (1999) assume that direct damage to assets (buildings, soil, machinery) which requires reconstruction or repurchase, as well as damage to flows (harvest), has consequences for transactions and employment in agricultural and 
commercial sectors. They evaluated these consequences using an input-output model.

\subsection{Hazard parameters}

For the 26 studies (in bold in Table 2), focusing on direct damage to agriculture, the analysis can also be completed by considering which hazard parameters were used to calculate direct damage and as a consequence, are considered to be the most influential. Here we focus on flood parameters which are generic and can be obtained from hydraulic models. As shown in Table 4, the flood parameters that can be used to construct damage functions for agriculture are the seasonality of the flood, water depth, duration, current velocity, deposits, contamination by pollution, and salinity of water. As mentioned in the introduction, the frequency of flooding may have a major influence on agricultural land use (through adaptation or abandonment of some activities), and thus on the damage corresponding. Nevertheless, flood frequency is not expected to have influence on damage for a stated land use. As a consequence, this parameter was not included in this review.

\subsubsection{Seasonality}

The great majority of the studies, (23 out of 26), took seasonality into account to assess crop damage. Only three studies did not consider the seasonality, Goulter and Morgan (1983), Hoes and Schuurmans (2006) and Jonkman et al. (2008). However, damage to agriculture was not the main focus of those studies. In most studies, the seasonality was accounted for by linking different damage coefficients to a season of the year. All the studies reviewed used a year as reference for the time scale and the steps can be monthly or a crop specific vegetative growth stage.

For other damage categories, the seasonality may not be as important for crop damage except for damage to plant material. Indeed, all the studies that considered damage to plant material also took the seasonality in damage functions into account. Brémond (2011) also considered the seasonality to assess damage to stocks.

Due to the seasonality of crop production, it is commonly agreed by the authors of the reviewed studies that seasonality is an essential parameter to take into consideration to define damage to crops and damage to perennial plant material. Nevertheless, all the reviewed studies used a year as time reference in damage functions. This choice is a serious problem for damage function transferability due to the high variability of the vegetative cycle of a crop depending on climatic conditions. For instance, it would be problematic to use crop damage functions defined in northern Europe for Mediterranean areas. As an example, wheat is harvested in July in southern Europe whereas in northern Europe, it may be harvested as late as August, depending on climatic conditions. It is thus crucial to focus methodological developments on the design of crop damage functions based on crop vegetative cycles. In this way, for each country, the time steps can be derived based on the crop vegetative cycle which will enable the transferability and mutualization of research efforts.

\subsubsection{Depth of water}

The second flood parameter considered in damage functions is water depth. Twenty studies used this parameter to assess crop damage (Table 4). It is generally the only parameter used to assess damage to farm buildings and their contents when these are taken into account (Blanc et al., 2010; Brémond, 2011; Dutta et al., 2003; Devaux-Ros, 2000; Erdlenbruch et al., 2007; SIEE et al., 2003). This parameter is also taken into account to evaluate damage to plant material and sometimes to soil (Agenais, 2010; Brémond, 2011; CA30, 2009; Devaux-Ros, 2000; Du Plessis and Viljoen, 1997).

\subsubsection{Duration}

Sixteen studies also used flood duration to assess damage to crops and to plant material. The usual time step used is the number of days of submersion. In these studies, it is difficult to know if flood duration refers to the duration of submersion, or also includes the time the soil takes to dry in the agricultural plots. Drying time varies considerably depending on soil texture. Thus, it would be more flexible to use duration of submersion in standard damage function and then to adapt the duration of soil drying by considering the local soil texture. Agenais (2010) took soil texture into account because drying duration is a major parameter when assessing the impacts of salinity on soil. In fact, for the same flood duration, damage to the soil and to the crop can differ significantly depending on soil texture. Moreover, flood duration is not always simulated in basic hydraulic models. Thus, when economic assessments of agricultural damage are to be undertaken, before launching hydraulic analysis, it is important to note that duration is a necessary parameter.

\subsubsection{Velocity}

Only six methods used water velocity to assess crop damage. these studies used qualitative thresholds to define velocity, e.g. low, medium, high velocity, in damage functions. This parameter is also used by the majority of authors who built damage functions for plant material because of potential uprooting (Brémond, 2011; CA30, 2009; Devaux-Ros, 2000; SIEE et al., 2003) and on soil for its potential impacts in terms of erosion (Brémond, 2011; CA30, 2009). None of the methods considered velocity when evaluating damage to farm buildings and their contents. For a detailed analysis of the velocity parameter in the evaluation of damage to domestic buildings, see Kelman and Spence (2004) or more recently Kreibich et al. (2009).

Like flood duration, velocity is not always simulated in classical hydraulic models. Consequently, hydraulic 
simulations including the analysis of velocity should be requested in advance if crop damage functions which consider this parameter are chosen. In practice, the need to consider velocity mainly depends on the type of local flood. For instance, if most of the local flooding events are flash floods, it is extremely important to pay more attention to this parameter.

\subsubsection{Deposit, contamination and salinity}

Silt transported by the water can settle on crops and affect yield. This is notably the case of meadows and Pierson et al. (1994) mentions the need for food complement for livestock. USACE (1985) also suggests taking potential deposits into account when assessing damage to crops.

As pointed by Roca et al. (2011), salt can also have specific impacts on crops and on soil. In the case of marine submersion, yield reduction is higher but also induced damage because of the toxicity of salt for soil (Agenais, 2010).

Contamination by pollution was not taken into account in the studies reviewed here, despite the fact it may be an important topic to be discussed when floodplain restoration is planned.

\subsubsection{Combination of parameters}

Most of the studies reviewed used a combination of several flood parameters to build damage functions. The most complex were crop damage functions. In the studies reviewed, one to five parameters were considered. USACE (1985) combined five flood parameters: seasonality, water depth, duration, velocity and deposit. Even if this study, which is more methodological, did not define complete crop damage functions, it showed that, depending on the local context, this parameters may have an influence on damage.

Brémond (2011) and CA30 (2009) combined four flood parameters: seasonality, water depth, duration, velocity to build crop damage function. The majority of the other studies reviewed used a combination of two or three flood parameters to build crop damage functions.

\subsection{Damage indicators}

Most flood damage assessment methods rely on two main stages: (1) quantifying flood impacts, (2) expressing these impacts in monetary values (Penning-Rowsell et al., 2005). Depending on how detailed the studies are, the first step was not always included in the report.

The correct damage indicator for economic assessment is the loss of added value or the cost of repair of material damage. However, several economic indicators can be used as a proxy for this. We analyzed how these indicators for crop damage and other farm components were used in the 26 studies (in bold in Table 2), focusing on direct damage to agriculture.

\subsubsection{Crop damage}

Concerning crop damage, the loss of added value corresponds to the decrease in product minus the variation in production costs due to flooding. Due to the loss of yield, some variable production costs may be saved while others may increase (treatment, tillage, for instance).

The Table 5 summarizes the economic indicators used in every study to evaluate crop damage.

Most of the studies quantitatively estimated the percentage of yield loss as a function of hazard parameters. Some studies, in particular agronomic ones, even ended the analysis at this stage (Poirée and Ollier, 1973; Duthion, 1982; Pierson et al., 1994; Satrapa et al., 2012).

Usually, the variation in product is directly monetized by applying the sales price to the variation in yield. Thus, some authors directly used the variation in gross product as a proxy for crop damage. This approximation means that the variation in production costs due to flooding is disregarded. Eleven studies used this indicator as a proxy for crop damage (Blanc et al., 2008; CA30, 2009; Consuegra Zammit, 1992; Deleuze et al., 1991; Dutta et al., 2003; Devaux-Ros, 2000; Erdlenbruch et al., 2007; Förster et al., 2008; Goulter and Morgan, 1983; Hoes and Schuurmans, 2006; McDonald, 1970). In contrast, Lacewell and Eidman (1972) used the net margin as proxy for crop damage, that is to say that all variable costs have been saved. In their updated study in 2006, Lacewell et al. (2006) added some additional production costs (additional treatment, tillage) to crop damage evaluation. Du Plessis and Viljoen (1997) used the gross product minus the harvesting costs.

In fact, the variation in production costs depends on the seasonality of the flood. USACE (1985) recommends considering the variation in production costs depending on the seasonality. For this purpose, it is necessary to collect data concerning the distribution of production costs over the year. Brémond (2011) developed a modelling approach that considers the crop management sequence and can determine the variable costs saved as a function of the seasonality. This method requires specific data on the production tasks required for each crop.

SIEE et al. (2003) propose to consider only two proxies: the gross product if the flood occurs at the end of the production cycle, the gross margin if the flood occurs at the beginning. This simplification may be acceptable if most of the floods occur at the beginning or at the end of the crop production cycle. However, which value should be taken in between remains a problem.

Following Morris and Hess (1988), the MultiCouloured Manual (Penning-Rowsell et al., 2005) recommends evaluating crop damage using the gross margin adjusted for variable costs that have been committed and cannot be saved in the event of a flood. This proxy was also used in Dunderdale and Morris (1997a). If a permanent change in land use is induced by a flood management project, then (Penning-Rowsell et al., 
Table 4. Flood hazard parameters taken into account to evaluate crop damage in the studies reviewed.

\begin{tabular}{|c|c|c|c|c|c|c|c|c|}
\hline Author & Season & Depth & Duration & Velocity & Deposit & Contamination & Salinity & Parameters \\
\hline Agenais (2010) & yes & - & yes & yes & - & - & yes & 4 \\
\hline Blanc et al. (2008) & yes & yes & - & - & - & - & - & 2 \\
\hline Brémond (2011) & yes & yes & yes & yes & - & - & - & 4 \\
\hline CA30 (2009) & yes & yes & yes & yes & - & - & - & 4 \\
\hline Consuegra Zammit (1992) & yes & - & yes & - & - & - & - & 2 \\
\hline Deleuze et al. (1991) & yes & yes & yes & - & - & - & - & 3 \\
\hline Devaux-Ros (2000) & yes & yes & - & yes & - & - & - & 3 \\
\hline Dunderdale and Morris (1997a) & yes & yes & - & - & - & - & - & 3 \\
\hline Du Plessis and Viljoen (1997) & yes & yes & yes & - & - & - & - & 3 \\
\hline Duthion (1982) & yes & - & yes & - & - & - & - & 2 \\
\hline Dutta et al. (2003) & yes & yes & yes & - & - & - & - & 3 \\
\hline Erdlenbruch et al. (2007) & yes & yes & - & - & - & - & - & 2 \\
\hline Förster et al. (2008) & yes & yes & yes & - & - & - & - & 3 \\
\hline Goulter and Morgan (1983) & - & yes & yes & - & - & - & - & 2 \\
\hline Hoes and Schuurmans (2006) & - & yes & - & - & - & - & - & 1 \\
\hline Jonkman et al. (2008) & - & yes & - & - & - & - & - & 1 \\
\hline Lacewell and Eidman (1972) & yes & yes & - & - & - & - & - & 2 \\
\hline Lacewell et al. (2006) & yes & yes & - & - & - & - & - & 2 \\
\hline McDonald (1970) & yes & yes & - & - & - & - & - & 2 \\
\hline Morris and Hess (1988) & yes & yes & yes & - & - & - & - & 3 \\
\hline Penning-Rowsell et al. (2005) & yes & yes & yes & - & - & - & - & 3 \\
\hline Pierson et al. (1994) & yes & - & yes & - & yes & - & - & 3 \\
\hline Poirée and Ollier (1973) & yes & - & yes & - & - & - & - & 2 \\
\hline Satrapa et al. (2012) & yes & - & - & - & - & - & - & 1 \\
\hline SIEE et al. (2003) & yes & yes & - & yes & - & - & - & 3 \\
\hline USACE (1985) & yes & yes & yes & yes & yes & - & - & 5 \\
\hline
\end{tabular}

2005) recommend considering the variation in fixed costs and resultant change in net margins at farm level.

To sum up, the studies we reviewed used several economic indicators depending on how the variable production costs were considered to be impacted by flood events. A really precise estimate of the variation in variable costs requires knowing the distribution of production costs over the year. If numerous flood events are simulated for several seasons of occurrence, the calculations should be automated.

\subsubsection{Damage indicators for the other farm components}

When material damage to farm components other than crop, i.e. damage to soil, buildings, machinery, stocks, is evaluated, the economic indicator used is the reparation cost. These reparation costs are evaluated by the cost of actions necessary to recover a status equivalent to the one before the flood event occurred or the costs of repurchasing what was lost.

Damage to soil is evaluated by cleaning costs and additional tillage, and gap filling which may have to be implemented depending on flood intensity. Among the only two methods that consider soil damage, CA30 (2009) used an aggregated indicator but did not explain which recovery tasks were included in soil damage. On the other hand, Brémond
(2011) details these tasks which allows adaptation of the methodology to local context.

Damage to farm buildings is usually evaluated by repair and cleaning costs. Concerning damage to machinery, damage is evaluated by the cost of repairing or repurchasing the machine. From an economic point of view, the correct value to be used to evaluate this damage is the depreciated value. Therefore, CA30 (2009) proposes to account for the age of the pool of machinery when defining a depreciation rate. It is also the assumption made by Brémond (2011) to evaluate damage to machinery.

In the studies reviewed which consider damage to plant material, the damage is usually evaluated by replanting costs and loss of added value before the orchard or vineyard reach their previous production potential.

\section{Analysis}

\subsection{Comparing ex-post and ex-ante studies}

Our review revealed a gap between ex-post studies (Sect. 2) and ex-ante studies (Sect. 3). All ex-post studies point out that besides crop damage, flood damage to agriculture includes damage to other farm components such as the soil in the plots, as well as farm building and contents. Moreover, 
Table 5. Economic indicators used for crop damage in the studies reviewed.

\begin{tabular}{ll}
\hline Author & Crop damage indicator* \\
\hline Agenais (2010) & Gross margin \\
Blanc et al. (2008) & Gross product \\
Brémond (2011) & Added value \\
CA30 (2009) & Gross product \\
Consuegra Zammit (1992) & Gross product \\
Deleuze et al. (1991) & Gross product \\
Devaux-Ros (2000) & Gross product \\
Dunderdale and Morris (1997a) & Gross margin adjusted with variable costs \\
Du Plessis and Viljoen (1997) & Gross product less harvesting cost \\
Duthion (1982) & Loss of yield \\
Dutta et al. (2003) & Gross product \\
Erdlenbruch et al. (2007) & Gross product \\
Förster et al. (2008) & Gross product \\
Goulter and Morgan (1983) & Gross product \\
Hoes and Schuurmans (2006) & Gross product \\
Jonkman et al. (2008) & - \\
Lacewell and Eidman (1972) & Net margin \\
Lacewell et al. (2006) & Net margin adjusted with additional production costs \\
McDonald (1970) & Gross product \\
Morris and Hess (1988) & Gross margin adjusted with variable costs \\
Penning-Rowsell et al. (2005) & Gross margin adjusted with variable costs \\
Pierson et al. (1994) & Loss of yield \\
Poirée and Ollier (1973) & Loss of yield \\
Satrapa et al. (2012) & Loss of yield \\
SIEE et al. (2003) & Gross product or gross margin \\
USACE (1985) & Variable \\
\hline
\end{tabular}

*The crop damage indicator is to understand as "the variation in" what is specified for each study. For example, for Agenais (2010), the crop damage indicator is the variation in gross margin.

they often point out that the appropriate scale to analyze damage to agriculture is the farm scale because some induced damage to farm activity may occur after flooding, especially because of disturbed work organization.

On the other hand, most of the ex-ante studies reviewed use different levels of simplifications. The simplifications encountered were:

1. considering few damage components, sometimes only crop damage;

2. simplifying the number of influencing parameters to design damage functions;

3. simplifying crop diversity;

4. considering agricultural buildings as domestic ones;

5. using proxy for the loss of added value;

6. considering farm components as separate, and not linked at farm level.

From the general analysis in Sect. 3.2, we suspect that most exchanges on methodology are limited to the national level and that little research is carried out on the transferability of local methodologies. One of the main difficulties for these exchanges is related to language, as developments are very often related to technical studies, written in the author's native language. Even at national level, exchanges between research and practitioner communities would improve the quality of economic evaluation. Thus, there appears to be a lack of exchanges at international level, which is not a stimulating context for the development and diffusion of knowledge.

The review also highlights the lack of data (experimental data or ex-post data collection) to construct damage functions. Specifically concerning crop damage, the review revealed that existing data to construct damage functions is limited and not up to date (Poirée and Ollier, 1973; Duthion, 1982).

Simplifications may also be related to the adaptation of methodologies to fit the availability of land use data. For instance, to evaluate crop damage, damage functions must correspond to the crop typology used in the land use description. But, most land use databases do not provide a detailed crop typology. The same problem can be encountered concerning the location and typology of agricultural buildings. Another difficulty may also be the attribution of a value to each type of agricultural building. The lack of land use data at farm 
scale may also be an obstacle to taking induced damage into account. In practice, it is often difficult to spatially identify plots and buildings belonging to a farm which is necessary to evaluate induced damage to farm activity.

Simplifications may also be related to some quantitative feedbacks from some ex-post studies. For instance, Posthumus et al. (2009) point that, for the event analyzed, a summer flood in England and Wales, the two components that generate the major part of damage were crops and livestock. This is coherent with the simplifications we have seen in most of ex-ante studies. However, most ex-post studies focus on major events, not on minor ones. This may have an implication on the distribution of damage within farm components. For instance, Brémond and Grelot (2010) confirmed this by simulating the distribution of damage to agriculture for several combinations of parameters, in particular the seasonality. It proves that depending on the season, total damage is in general low, when crop damage is low. However, damage to other farm components such as soil or farm buildings and their contents as well as potential induced damage to farm activity do not vary in the same proportion, and so may represent a large share of the total damage. We discuss later the possible implications for economic valuation (Sect. 4.2.2).

Considering the monetized damage indicators, rigorous methodologies exist and it is clear that the economic damage should be evaluated by the loss of added value. For crop damage, this implies considering the variation in production costs as a function of the seasonality. In practice, calculating the loss of added value requires knowing farmers' practices and the distribution of production costs over the year for each crop.

Flood parameters to be considered to evaluate flood damage to agriculture are, a priori, specific compared to other sectors. Seasonality and duration are identified as the most influencing parameters. However, this review revealed that identifying the combination of flood parameters which need to be considered for each damage category is extremely complex.

\subsection{Application for Cost-Benefit Analysis (CBA)}

\subsubsection{Principles of CBA and particularities related to agriculture}

CBA is recognised as the major appraisal technique for public investments and public policy (Pearce et al., 2006). It relies on the comparison of options to determine which one is the most efficient. Economic efficiency is based on the difference between the social costs and social benefits of an option (Brent, 2006). Costs and benefits are "social", because any person impacted by an option is to be considered in the scope of the analysis. Ideally, to be sure that an option (option 1) is socially preferred to another (option 2), a Pareto improvement should be achieved: in this case, there are some people who prefer the option 1 , and there is nobody who prefers option 2. As this situation is exceptionnal, the notion of potential Pareto improvement has been introduced, based on the Kaldor-Hicks compensation principle (Pearce et al., 2006). This principle states that if an hypothetical mechanism of compensations can be made between people preferring option 1 and people preferring option 2, such as people compensating are still preferring option 1 , while the others are sufficiently compensated to prefer option 1 , then option 1 is socially prefered.

Theoretically, benefits are defined as increases in human well-being and costs are defined as reductions in human wellbeing (Pearce et al., 2006). This imply to define what is the situation of reference (very often called the "do-nothing option"): benefits (respectively costs) correspond to increases (reductions) of human well-being when comparing the situation expected with the project to the situation of reference. The definition of the situation of reference is not straightforward but out of the scope of this article. For any further detail on the economic principles of CBA, see Pearce et al. (2006). To define what is a cost and what is a benefit, the perspective chosen is that of the collectivity funding the projet. Very often, the scale should be that of the state where the project is planned. However, as the analysis is based on comparison of two situations, the focus is made on where the changes are supposed to take place, which may justify to reduce the scale of analysis. Another important point is linked to the compensation principle stating that some costs may be compensated by some benefits. The justification for considering this compensation mechanism depends on the scale used for CBA: if some benefits result in costs out of the chosen perimeter for analysis, no compensation is to be taken into account. Not considering compensations occuring inside this perimeter may lead to a bias.

Concerning flood management projects, the method generally used to estimate benefits is the so-called method of "avoided damage" (Shabman and Stephenson, 1996; Penning-Rowsell et al., 2005). As a consequence, the benefits are usually the avoided damage resulting from project implementation and the costs are the costs of project (implementation and maintenance costs) added to the monetized value of negative impacts of the project. For example, in the case of floodplain restoration, additional damage to agriculture are to be considered as costs of the project. More precisely, avoided damage corresponds to expected annual avoided damage, which is the difference between expected annual damage in the situation of reference and expected annual damage with the project implemented. Expected annual damage corresponds to the average of flood damages computed over many years (Arnell, 1989).

When flood management projects concern agriculture, the change in flood protection standards may induce change in agricultural land use. Then, the approach to appraisal depends on the value of agricultural assets and their related productivity that are put at risk, temporarily or permanently, as a consequence of changes in flood protection standards. 
These specificities are fully detailed in Penning-Rowsell et al. (2005, p. 183-206). Depending on the increase in flood frequency related to the project, several scenarios are possible. For instance, the Flood and Coastal Defence Project Appraisal Guidance from MAFF (1999), updated by DEFRA (2008), recommends distinguishing three scenarios:

1. Land is abandoned or no longer suitable for agriculture.

2. Occasional losses of output.

3. Permanent reduction in agricultural output per hectare.

A method to evaluate damage to agriculture is recommended for each scenario. For the first scenario, it is advised to evaluate economic damage by the reduction in market value of agricultural land, adjusted for subsidy effects. For the second scenario, it is assumed that one off damages occur to crops that are already in place. In such cases, it is recommended to use the reduction in gross margin adjusted to allow for any savings in avoidable production costs. In the third scenario, a change in flood incidence induces significant permanent changes in the agricultural productivity, possibly involving land use change. Here, changes in gross margins and net margins allowing for changes in fixed costs at the farm scale should be considered. Considering these scenarios is critical before undertaking a CBA. As explained in the introduction, although the issue of identification of future land use scenarios is required for economic appraisal of projects, it is out of the scope of this article. However, it may have impact on the relevency of ex-ante studies if those studies do not consider all the possible land use when assessing damage functions.

For projects such as the construction of dykes, which mainly aim at protecting urban areas, the simplification on agricultural damage evaluation may be of minor importance due to the small share of agricultural damage in the total amount of damage. However, the suitability of these methods to evaluate new flood risk management options, in which agriculture plays a major role, needs to be considered. This is done in Sect. 4.2.2 for floodplain restoration.

Farms may receive subsidies, which payment may be dependent on the fulfilment of harvest. In such case, crop damage may result on loss of subsidies (Morris and Brewin, 2013). Although, from the farm's perspective, this loss of subsidies is a loss of income, it is commonly agreed in economics, that it should not be included in the scope of CBA. The reason is that subsidies are considered as financial transfers within the society, what farmers loose is compensated by what subsidizer gains.

\subsubsection{Suitability of existing ex-ante methods to assess floodplain restoration}

Flood risk management options such as floodplain restoration or creation of retention areas raise new issues for damage assessment that may not be addressed in current practice. Projects including options of this type aim to increase flood exposure of areas which are supposed to generate less damage, often agricultural areas, to protect areas which are supposed to generate more damage such as urban areas.

From the point of view of economic evaluation, this raises two issues: efficiency and equity.

Firstly, to evaluate the efficiency of these projects, methods with comparable accuracy must enable evaluation of damage to agricultural and urban areas. Basically, the damage to agricultural areas, which are more exposed, represent part of the cost of the project with implementation costs whereas avoided damage to urban areas represent the benefits. Based on efficiency criteria, additional damage to agriculture and project implementation costs should be compensated by avoided damage to areas which benefit from higher protection, i.e. urban areas. Thus, for the correct evaluation of this kind of project, it is crucial to avoid underestimating the costs of the project and to pay attention to agricultural damage evaluation.

Secondly, these projects clearly designate visible losers and winners in terms of benefits and costs. Farmers who will be more exposed, will suffer more damage and urban areas will be more protected. In classical CBA, the Kaldor-Hicks compensation principle states that hypothetical compensation is sufficient to achieve a potential Pareto improvement (Pearce et al., 2006). In the case of floodplain restoration, this would mean that additional damage to agricultural areas does not need to be compensated in practice in order that the project is considered economically efficient. However, the analysis of feedback experience on floodplain restoration in France shows that real compensation is an indispensable lever for effective implementation (Erdlenbruch et al., 2009). For a review of compensation to land managers for flood risk management services, see Beedell et al. (2012). The difficulty involved in reaching agreement on compensation during the negotiation process between farmers and decision makers, is one of the main barriers to implementation. This calls for the development of methods to evaluate agricultural damage that accurately reflect the damage suffered by farmers.

As a consequence of the previous remarks, it is clear that the evaluation and the implementation of projects including floodplain restoration options require methods which accurately represent the damage suffered by farmers to evaluate additional flood damage to agriculture. Existing methods tend to focus on crop damage and mainly use only two or three flood parameters. But floodplain restoration results in complex changes in flood parameters in terms of frequency, seasonality (i.e. at which time of the season the flood occurs), depth, velocity, and duration of the flood. As a consequence, existing methods, specifically those which only consider crop damage may not be sufficient. For example, the probability of occurrence of flood events in the downstream Rhone River is the higher in winter. At this season, 
the amount of crop damage is low for most crops. But, as shown in Sect. 3.3, qualitative studies also highlight the importance of other damage categories, particularly, recovery and cleaning process after flooding. As stated before, the study by Brémond and Grelot (2010) has shown that, in winter, even if crop damage is low, damage to other farm components such as soil or farm buildings and their contents as well as potential induced damage to farm activity may represent a large share of the total damage. Not considering this aspect may be crucial when using expected annual damage: for instance, Merz et al. (2009) have shown that this indicator is dominated by "high probability/low damage" events for all the case studies they tested, and for the general case of river floods in Germany.

Moreover, farmers may also be reluctant to accept floodplain restoration due to potential contamination by flood water. The link between soil contamination and flooding remains little investigated to date. The difficulty to monetize this damage is not due to a lack of economic method but to the need to better understand biophysical contamination processes occurring after flooding to be able to quantify them (Sauer et al., 2007; Schulz et al., 2007).

Finally, farmers may be exposed to an increased risk of bankruptcy, directly linked to flood exposure. To explore this risk, damage assessment methods need to consider the farm as a system.

\section{Recommendations for future research}

Based on the conclusions from the review, we provide in this section, some recommendations for future research and analyze their potential advantages.

The review of methods to evaluate flood damage to agriculture revealed that crop damage is generally acknowledged to be critical. Nevertheless, the review also showed that many simplifications have been made in existing damage functions. One likely reason highlighted by the review is that existing data on crop damage are scant and dated. Consequently whereas most research efforts have been focused on crop damage up to now, some improvements are required. There is a clear need to consolidate crop damage functions.

To this end, two approaches are possible: experimentation or collecting data on damage after flood events. Experimentation does not seem the most promising way since it requires a lot of effort and does not correspond to methods used to evaluate damage in other sectors. In our opinion, further research should be carried out to collect, compare and homogenize expert knowledge on flood damage to crops and to farmers' practices after flooding. As flood events are occasional, data from different ex-post studies need to be collected and processed to construct damage functions. To this end, exchange of knowledge from different countries would be helpful. To facilitate such exchange and enable the transferability of crop damage functions, we recommend using the vegetative growth stage as temporal scale. In this way, crop damage functions could be adapted in countries with different climates. To evaluate the loss of added value due to crop damage, also requires determining the variation in production costs. To do so, it is necessary to collect data on farmers' practices depending on crop damage; e.g. to understand if the variation in production costs is proportional to yield loss.

The review also showed that existing ex-ante studies to evaluate damage to agriculture often consider too few damage categories, sometimes only crop damage, although expost studies point out that other farm components are also impacted. Although no cost estimates are provided in this review, it is clear that damage to agricultural buildings or perennial crops can represent a large proportion of total damage, if these assets are impacted by a flood. We thus identified a need for methods to evaluate flood damage to farm components other than crops i.e. soil, plant material, farm buildings and their contents. Consolidating damage functions on every farm component requires collecting and analyzing expert knowledge. This could be undertaken at the same time as collecting expert knowledge on crop damage. Even if damage to agriculture is generally considered to be less important than damage to other sectors, considering new flood risk management options, it is now necessary to have a precise evaluation. The evaluation of damage to farm components other than crops would allow a more precise evaluation of the economic efficiency of flood management projects.

To more accurately evaluate crop damage as well as damage to other farm components, we underline the need to better organize the collection of data on damage after flood events in order to facilitate exchange and transferability. To this end, it is the role of research community to clearly express the data needed (type, aggregation level, format) for economic evaluation so that data collection could be facilitated in the aftermath of flooding.

Due to this lack of data, the issue of damage model validation is also very difficult to solve. More systemic and organized data collection would also help to match results from simulations with observed damage.

Moreover, as shown by Merz et al. (2004) and Merz and Thieken (2009) in other sectors (damage to buildings), improvement of flood damage estimation may benefit from uncertainty analysis. Our review has shown that this type of analysis is rarely done. Nevertheless, as damage to agriculture appears to be a complex combination of hazard characteristics with farm components, such an analysis is necessary to address the quality of models estimated on the basis of available data. Moreover, we recommend to better explore the need for complexity and possible simplifications with approaches such as developed by Merz et al. (2013) in the field of damage assessment, or more generally, such as global sensitive analysis (Saltelli et al., 2007). This would particularly useful to analyse what are the flood parameters to be considered to evaluate flood damage. 
Finally, this review highlighted the fact that most of the studies consider agriculture not as an economic system but, rather, as a collection of plots defined by a certain crop type. However, to evaluate induced damage to activity, i.e. loss of added value due to the disturbance or disruption of activity, a farm scale approach is needed. The methodology developed by Brémond (2011) is a first step which now needs to be tested in several local contexts. Besides the improvement in the evaluation of related agricultural damage due the integration of loss of activity, adopting a farm scale approach would substantially help to analyze farmers' motivations in accepting measures such as payment for ecosystem services and adaptation measures.

Acknowledgements. This work has benefited from the support of Plan Rhône (FEDER funding), Syndicat d'Aménagement de la Touloubre, French Ministry of the Environment (DGPR, CGDD). This paper received especially helpful and detailed comments from J. Morris and one anonymous referee.

Edited by: L. Bouwer

Reviewed by: J. Morris and one anonymous referee

\section{References}

Agenais, A.-L.: Évaluation économique des dommages liés à la submersion marine sur l'agriculture. Construction d'un modẽle et application au Languedoc-Roussillon, Mémoire de fin d'études présenté pour l'obtention du diplôme d'ingénieur agronome, spécialisation territoires et ressources: Politiques publiques et acteurs, Montpellier Sup'Agro, Montpellier, France, 2010 (in French).

Arnell, N. W.: Expected Annual Damages and Uncertainties in Flood Frequency Estimation, J. Water Resour. Plan. Manage., 115, 94-107, 1989.

Barbut, L., Bauduceau, N., and Devaux-Ros, C.: Vers une évaluation de la vulnérabilité des activités agricoles aux inondations, Ingénieries Eau-Agriculture-Territoires, 39, 29-41, 2004 (in French).

Bauduceau, N.: Éléments d'analyse des répercussions des inondations de novembre 1999 sur les activités agricoles des départements de l'Aude, des Pyrénées Orientales et du Tarn, Tech. rep., Équipe pluridisciplinaire Plan Loire Grandeur Nature, 2001 (in French).

Bauduceau, N.: Rapport de synthèse sur les mesures de réduction de la vulnérabilité des exploitations agricoles face au risque d'inondation, Tech. rep., Agence de l'Eau Loire-Bretagne, 2004a (in French).

Bauduceau, N.: De la caractérisation de la vulnérabilité de l'exploitation agricole face au risque d'inondation à la production d'un outil opérationnel de réduction de la vulnérabilité, Tech. rep., Équipe Pluridisciplinaire Plan Loire Grandeur Nature, 2004b (in French).

Beedell, J., Morris, J., and Hess, T. M.: Land owner compensation and approaches for flood protection work - Mobilising the contribution of Rural Land Management to Flood Risk Manage- ment in Scotland, Tech. rep., Report to Scottish Government, Ref CR/2010/14, 2012.

Berning, C., Viljoen, M. F., and Du Plessis, L. A.: Loss functions for sugar-cane: Depth and duration of inundation as determinants of extent of flood damage, Water SA, 26, 527-530, 2000.

Blanc, C.: L'analyse coût-bénéfice des aménagements pour lutter contre les inondations. Le cas de la Touloubre, Rapport pour le syndicat d'aménagement de la touloubre, Cemagref, 2008 (in French).

Blanc, C., Brémond, P., Erdlenbruch, K., Grelot, F., Mériaux, P., and Tourment, R.: Étude préalable à l'analyse économique de la gestion des zones agricoles surinondées du bassin versant de la Touloubre, Rapport pour le syndicat d'aménagement de la touloubre, Cemagref, 88 pp., 2008 (in French).

Blanc, C., Brémond, P., and Grelot, F.: Projet EVA Évaluation de la Vulnérabilité Agricole, Rapport pour la mission rhône, DREAL Rhône-Alpes, Cemagref, 267 pp., 2010 (in French).

Bournot, A.: Évaluation de la pertinence des mesures de gestion du risque d'inondation, Manuel des pratiques existantes, Tech. rep., CEPRI, 2008 (in French).

Brémond, P.: Caractérisation et évaluation économique de la vulnéabilité des exploitations agricoles aux inondations, Thèse de doctorat, spécialité sciences Économiques, Université de Montpellier 1, Montpellier, France, 2011 (in French).

Brémond, P. and Grelot, F.: Comparison of a systemic modelling of farm vulnerability and classical methods to appraise flood damage on agricultural activities, in: Advancing Sustainability in a Time of Crisis, 11th biennal conference of the International Society for Ecological Economics, August 22-25, Oldenburg and Bremen, Germany, 2010.

Brémond, P. and Grelot, F.: Taking into account recovery to assess vulnerability: application to farms exposed to flooding, in: Managing Resources of a Limited Planet, 2012 International Congress on Environmental Modelling and Software, edited by: Seppelt, R., Voinov, A. A., Lange, S., and Bankamp, D., International Environmental Modelling and Software Society, Leipzig, Germany, 2012.

Brémond, P., Breton, C., Erdlenbruch, K., Enjolras, G., Grelot, F., Kast, R., Thoyer, S., Chastan, B., and Poulard, C.: Expertise des pratiques de compensation en cas de transfert d'exposition aux inondations, Tech. rep., Ministère de l'Écologie, du Développement Durable, des Transports et du Logement, 2007 (in French).

Brémond, P., Bauduceau, N., and Grelot, F.: Characterizing Agriculture Vulnerability for Economic Appraisal of Flood Management Policies, in: 4th International Symposium on Flood Defence: Managing Flood Risk, Reliability and Vulnerability, Institute for Catastrophic Loss Reduction, Toronto, Ontario, Canada, 2008.

Brent, R. J.: Applied cost-benefit analysis, Edward Elgar Publishing, Cheltenham, UK - Northampton, MA, USA, 2nd Edn., 2006.

Bubeck, P., de Moel, H., Bouwer, L. M., and Aerts, J. C. J. H.: How reliable are projections of future flood damage?, Nat. Hazards Earth Syst. Sci., 11, 3293-3306, doi:10.5194/nhess-11-32932011, 2011.

CA30: Étude des enjeux agricoles sur la plaine de Bellegarde/Fourques et couloir de Saint-Gille dans le cadre de l'étude de renforcement de la digue du Rhône rive droite entre Beaucaire et Fourques, Tech. rep., Chambre d'Agriculture du Gard 
pour le compte du SYMADREM, Nîmes, France, 148 pp., 2009 (in French).

Chatterton, J., Viavattene, C., Morris, J., Penning-Rowsell, E., and Tapsell, S.: The Costs of the Summer 2007 Floods in England, Tech. rep., Environment Agency, 2010.

Citeau, J.-M.: A New Flood Control Concept in the Oise Catchment Area: Definition and Assessment of Flood Compatible Agricultural Activities, in: FIG (Fédération Internationale des géométres) Working Week, école Nationale de Sciences Géographiques (ENSG) et Institut de Géographie Nationale (IGN), 13-17 April, Marne la Vallée, Paris, 2003 (in French).

Consuegra Zammit, D.: Concept de gestion des eaux de surface: aspects méthodologiques et application au bassin versant de la Broye en Suisse, Ph.D. thesis, École Polytechnique Fédérale de Lausanne, Lausanne, Suisse, 228 pp., 1992 (in French).

DEFRA: Flood and Coastal Defence Appraisal Guidance Economic Appraisal. Supplementary Note to Operating Authorities: Valuation of Agricultural Land and Output for Appraisal Purposes, Tech. rep., DEFRA, 2008.

Deleuze, C., Fotre, C., Nuti, I., and Pierot, F.: Évaluation de fonctions de coûts économiques des dommages aux cultures dus aux inondations, Master's thesis, ENGREF, 1991 (in French).

Devaux-Ros, C.: Évaluation des enjeux et des dommages potentiels liés aux inondations de la Loire moyenne, Méthodes et principaux résultats, Tech. rep., Équipe pluridisciplinaire Plan Loire Grandeur Nature, 2000 (in French).

Du Plessis, L. A. and Viljoen, M.: Die ontwikkeling van vloedskadefunksies vir die landbousektor in die Benede-Oranjerivier, Water SA, 23, 209-216, 1997 (in Afrikaans).

Du Plessis, L. A. and Viljoen, M. F.: Estimation of total direct flood damage in the lower Orange River area with the aid of a flood simulation model - A GIS approach, Water SA, 24, 201-204, 1998.

Du Plessis, L. A. and Viljoen, M. F.: Calculation of the secondary effects of floods in the lower Orange River area - A GIS approach, Water SA, 25, 197-203, 1999.

Dunderdale, J. A. L. and Morris, J.: Agricultural Impacts of River Maintenance Activities: A Method of Assessment, J. Agr. Eng. Res., 68, 317-327, 1997a.

Dunderdale, J. A. L. and Morris, J.: The Benefit-Cost Analysis of River Maintenance, J. Chartered Inst. Water Environ. Manage., 11, 423-430, 1997b.

Dury, B. and Didier, C.: Activité économique agricole, foncier et environnement écologique du casier d'inondation de Saint-Maurice en Rivière à Allériot, Phase II : chiffrage des impacts agricoles, Tech. rep., Chambre d'Agriculture 71 pour le compte du Syndicat Mixte Saône-Doubs, Mâcon, France, 2006 (in French).

Duthion, C.: Effets d'une courte période d'excès d'eau sur la croissance et la production du maïs, Agronomie: sciences des productions végétales et de l'environnement, 2, 125-131, 1982 (in French).

Dutta, D., Herath, S., and Musiake, K.: A mathematical model for flood loss estimation, J. Hydrol., 277, 24-49, 2003.

Erdlenbruch, K., Germano, V., Gilbert, É., Grelot, F., and Lescouliers, C.: Étude socio-économique des inondations sur le bassin versant de l'Orb, Document final GRI 60306K, Conseil Général de l'Hérault, Montpellier, France, 2007 (in French).

Erdlenbruch, K., Thoyer, S., Grelot, F., Kast, R., and Enjolras, G.: Risk-sharing policies in the context of the French Flood Pre- vention Action Programmes, J. Environ. Manage., 91, 363-369, 2009.

Förster, S., Kuhlmann, B., Lindenschmidt, K.-E., and Bronstert, A.: Assessing flood risk for a rural detention area, Nat. Hazards Earth Syst. Sci., 8, 311-322, doi:10.5194/nhess-8-311-2008, 2008.

Gayler, D., Chilvers, M., Abrahams, J., Coghlan, A., Koob, P., Kuslap, A., Casinader, T., Schneider, J., Brown, R., Gabriel, P., Gauntlett, I., Buckle, P., Galloway, L., Hoffman, G., Henri, C., Kilby, C., and Amiel, L.: Economic costs of natural disasters in Australia, Tech. rep., Bureau of Transport Economics, Commonwealth of Australia, Canberra, Australia, 2001.

Gilard, O.: Les bases techniques de la méthode Inondabilité, Cemagref Éditions, 1998 (in French).

Goulter, I. C. and Morgan, D. R.: Analyzing Alternative Flood Damage reduction Measures on Small Watersheds Using Multiple return Period Floods, Water Resour. Res., 19, 1376-1382, 1983.

Hess, T. M. and Morris, J.: Estimating the Value of Flood Alleviation on Agricultural Grassland, Agr. Water Manage., 15, 141$153,1988$.

Hoes, O. and Schuurmans, W.: Flood standards or risk analyses for polder management in the Netherlands, Irrigation Drainage, 55, S113-S119, 2006.

Johnson, C. L., Penning-Rowsell, E. C., and Parker, D. J.: Natural and imposed injustices: the challenges in implementing fair flood risk management policy in England, Geographical J., 173, 374390, 2007a.

Johnson, C. L., Penning-Rowsell, E. C., and Tapsell, S.: Aspiration and reality: flood policy, economic damages and the appraisal process, Area, 39, 214-223, $2007 \mathrm{~b}$.

Jonkman, S. N., Bockarjova, M., Kok, M., and Bernardini, P.: Integrated hydrodynamic and economic modelling of flood damage in the Netherlands, Ecol. Econom., 66, 77-90, 2008.

Kelman, I. and Spence, R.: An overview of flood actions on buildings, Eng. Geol., 73, 297-309, 2004.

Kreibich, H., Piroth, K., Seifert, I., Maiwald, H., Kunert, U., Schwarz, J., Merz, B., and Thieken, A. H.: Is flow velocity a significant parameter in flood damage modelling?, Nat. Hazards Earth Syst. Sci., 9, 1679-1692, doi:10.5194/nhess-9-1679-2009, 2009.

Lacewell, R. D. and Eidman, V. R.: A proposed procedure for distributing assessments among beneficiaries of small watershed projects, Southern J. Agr. Econom., 2, 139-145, 1970.

Lacewell, R. D. and Eidman, V. R.: A General Model for Evaluating Agricultural Flood Plains, Am. J. Agr. Econom., 54, 92-101, 1972.

Lacewell, R. D., Freeman, R., Petit, D., Rister, M. E., Sturdivant, A. W., Ribera, L., and Zinn, M.: Update of Estimated Agricultural Benefits Attributable to Drainage and Flood Control in Willacy County, Texas, Texas Water Resources Institute Report TR-294, Texas Water Ressource Institute, 2006.

Lekuthai, A. and Vongvisessomjai, S.: Intangible Flood Damage Quantification, Water Resour. Manage., 15, 343-362, 2001.

MAFF: Flood and Coastal Defence Project Appraisal Guidance. Economic Appraisal, Tech. Rep. FCDPAG3, Ministry of Agriculture, Fisheries and Food, 1999.

Markantonis, V., Meyer, V., and Schwarze, R.: Review Article "Valuating the intangible effects of natural hazards - review and anal- 
ysis of the costing methods", Nat. Hazards Earth Syst. Sci., 12, 1633-1640, doi:10.5194/nhess-12-1633-2012, 2012.

McDonald, G. T.: Agricultural Flood Damage Assessment: A Review and Investigation of a Simulation Method, Rev. Market. Agr. Econom., 38, 105-120, 1970.

Merz, B. and Thieken, A. H.: Flood risk curves and uncertainty bounds, Nat. Hazards, 51, 437-458, 2009.

Merz, B., Kreibich, H., Thieken, A., and Schmidtke, R.: Estimation uncertainty of direct monetary flood damage to buildings, Nat. Hazards Earth Syst. Sci., 4, 153-163, doi:10.5194/nhess-4-1532004, 2004.

Merz, B., Elmer, F., and Thieken, A. H.: Significance of "high probability/low damage" versus "low probability/high damage" flood events, Nat. Hazards Earth Syst. Sci., 9, 1033-1046, doi:10.5194/nhess-9-1033-2009, 2009.

Merz, B., Kreibich, H., Schwarze, R., and Thieken, A.: Review article "Assessment of economic flood damage", Nat. Hazards Earth Syst. Sci., 10, 1697-1724, doi:10.5194/nhess-10-16972010, 2010.

Merz, B., Kreibich, H., and Lall, U.: Multi-variate flood damage assessment: a tree-based data-mining approach, Nat. Hazards Earth Syst. Sci., 13, 53-64, doi:10.5194/nhess-13-53-2013, 2013.

Meyer, V. and Messner, F.: National Flood Damage Evaluation Methods. A Review of Applied Methods in England, the Netherlands, the Czech Republic and Germany, Deliverable of task 9 of FLOODSite project 2_0_P44, UFZ - Department of Economics, 2005.

Meyer, V., Becker, N., Markantonis, V., Schwarze, R., Aerts, J. C. J. H., van den Bergh, J. C. J. M., Bouwer, L. M., Bubeck, P., Ciavola, P., Daniel, V. E., Genovese, E., Green, C. H., Hallegatte, S., Kreibich, H., Lequeux, Q., Lochner, B., Logar, I., Papyrakis, E., Pfurtscheller, C., Poussin, J., Przyluski, V., Thieken, A. H., Thompson, P. M., and Viavattene, C.: Costs of Natural Hazards - A Synthesis, Conhaz - wp09 final report, UFZ, Leipzig, Germany, 2012.

MLIT: Manual for Economic Appraisal of Flood Control Projects, Tech. rep., (Japanese) Ministry of Land, Infrastructure, Transport, and Tourism - River Burea), Tokyo, Japan, available at: http://www.mlit.go.jp/river/basic_info/seisaku_hyouka/ gaiyou/hyouka/h1704/chisui.pdf, 112 pp. , 2005 (in Japanese).

Morris, J.: Agricultural land drainage, land use change and economic performance; experience in the UK, Land Use Policy, 9, 185-198, 1992.

Morris, J. and Brewin, P.: The impact of seasonal flooding on agriculture: the spring 2012 floods in Somerset, England, J. Flood Risk Manage., doi:10.1111/jfr3.12041, online first, 2013.

Morris, J. and Hess, T. M.: Agricultural flood alleviation benefit assessment: A case study, J. Agr. Econom., 39, 402-412, 1988.

Morris, J., Gowing, D. J. G., Mills, J., and Dunderdale, J. A. L.: Reconciling agricultural economic and environmental objectives: The case of recreating wetlands in the Fenland area of eastern England, Agr. Ecosyst. Environ., 79, 245-257, 2000.

Morris, J., Hess, T. M., Gowing, D. J., Leeds-Harrison, P. B., Bannister, N., Wade, M. P., and Vivash, R. M.: Integrated Washland Management for Flood Defence and Biodiversity. Report to Department for Environment, Food and Rural Affairs \& English Nature, English Nature Research Reports Number 598, Cranfield University, Silsoe, Bedfordshire, UK, 2004.
Morris, J., Bailey, A. P., Lawson, C. S., Leeds-Harrison, P. B., Alsop, D., and Vivash, R. M.: The economic dimensions of integrating flood management and agri-environment through washland creation: A case from Somerset, England, J. Environ. Manage., 88, 372-381, 2008.

Neubert, G. and Thiel, A.: Schadenpotentiale in der Landwirtschaft, in: Möglichkeiten zur Minderung des Hochwasserrisikos durch Nutzung von Flutpoldern an Havel und Oder, edited by: Bronstert, A., chap. 5, 117-140, Universität Potsdam, Postdam, Germany, 2004 (in German).

Parker, D. J., Green, C. H., and Thompson, P. M.: Urban flood protection benefits: A project appraisal guide (The Red Manual), Gower Technical Press, Aldershot, Hants, England, 1987.

Pearce, D. W., Atkinson, G., and Mourato, S.: Cost-Benefit Analysis and the Environment. Recent Developments, Organisation for Economic Co-operation and Development, 2006.

Penning-Rowsell, E. C. and Chatterton, J. B.: The benefits of flood alleviation: A manual of assessment techniques (The Yellow manual), Saxon House, Farnborough, England, 1977.

Penning-Rowsell, E. C., Green, C. H., Thompson, P. M., Coker, A. M., Tunstall, S. M., Richards, C., and Parker, D. J.: The economics of coastal management: a manual of benefit assessment techniques, (The Blue Manual), Belhaven Press, London, England, 1992.

Penning-Rowsell, E. C., Johnson, C. L., Tunstall, S. M., Tapsell, S., Morris, J., Chatterton, J., and Green, C. H.: The Benefits of Flood and Coastal Risk Management: A Handbook of Assessment Techniques, Flood Hazard Research Centre, Middlesex University Press, 2005.

Pierson, F., Barneoud, C., Vinatier, J.-M., Amiet, Y., Hermant, A., Grandidier, I., de la Rocque, T., Kockmann, F., Villard, A., Matt, J.-P., Chrétien, J., and Dupont, B.: Étude de l'agriculture dans les champs d'inondation de la vallée de la Saône. Aptitudes agronomiques, Tech. rep., Chambre Régionale d'Agriculture de Bourgogne pour le compte du Syndicat Mixte d'étude pour l'Aménagement du Bassin de la Saône et du Doubs, Quétigny, France, 184 pp., 1994 (in French).

Pivot, J.-M., Josien, E., and Martin, P.: Farms adaptation to changes in flood risk: a management approach, J. Hydrol., 267, 12-25, 2002.

Poirée, M. and Ollier, C.: Assainissement agricole: drainage par tuyaux ou fossés, aménagement des cours d'eau et émissaires, Eyrolles, Paris, France, 1973 (in French).

Posthumus, H., Morris, J., Hess, T. M., Neville, D., Philips, E., and Baylis, A.: Impacts of the summer 2007 floods on agriculture in England, J. Flood Risk Manage., 2, 182-189, 2009.

Posthumus, H., Rouquette, J. R., Morris, J., Gowing, D. J. G., and Hess, T. M.: A framework for the assessment of ecosystem goods and services; a case study on lowland floodplains in England, Ecol. Econom., 69, 1510-1523, 2010.

Riddel, K. and Green, C. H.: Flood and Coastal Defence Project Appraisal Guidance. Economic Appraisal, Tech. Rep. FCDPAG3, Ministry of Agriculture, Fisheries and Food, Flood and Coastal Defence with Emergencies Division, United Kingdom, a procedural guide for operating authorities, 1999.

Roca, M., Bast, H., Panzeri, M., Hess, T. M., Sayers, P., Flikweert, J., Ogunyoye, F., and Young, R.: Developing the evidence base to describe the flood risk to agricultural land in England and Wales, R\&D Technical Report FD2634/TR, DEFRA, 2011. 
Rouquette, J. R., Posthumus, H., Gowing, D. J. G., Tucker, G., Dawson, Q. L., Hess, T. M., and Morris, J.: Valuing natureconservation interests on agricultural floodplains, J. Appl. Ecol., 46, 289-296, 2009.

Saltelli, A., Ratto, M., Andres, T., Campolongo, F., Cariboni, J., Gatelli, D., Saisana, M., and Tarantola, S.: Global Sensitiviy Analysis, The primer, Wiley, 2007.

Satrapa, L., Fošumpaur, P., Horský, M., Brouček, M., and Nešvarová, P.: Posuzování účinnosti akcí protipovodňové ochrany v rámci činnosti strategického experta programu Prevence před povodněmi v ČR, Czech Technical University, [Translated title: Assessing the effectiveness of flood protection in the work Expert Strategic Flood Prevention Program in the Czech Republic], 2012 (in Czech).

Sauer, A., Schanze, J., and Walz, U.: Development of a GISbased Risk Assessment Methodology for Flood Pollutants, in: Information Technologies in Environmental Engineering, edited by: Gómez, J. M., Sonnenschein, M., Müller, M., Welsch, H., and Rautenstrauch, C., Environmental Science and Engineering, 357-366, Springer Berlin Heidelberg, 2007.

Schulz, M., Büttner, O., Matthies, M., Böhme, M., and Tümpling, W.: Modeling Arsenic and Oil Contamination After High Water Events in the Town and Floodplain of Bitterfeld (Germany), in: Information Technologies in Environmental Engineering, edited by Gómez, J. M., Sonnenschein, M., Müller, M., Welsch, H., and Rautenstrauch, C., Environmental Science and Engineering, 367-376, Springer Berlin Heidelberg, 2007.

Shabman, L. and Stephenson, K.: Searching for the Correct BenefitEstimates: Empirical Evidence for an Alternative Perspective, Land Economics, 72, 433-449, 1996.
SIEE, EDATER, AScA, and TTI: Étude globale pour une stratégie de réduction des risques dus aux crues du Rhône, Lot 4 : Analyse de l'occupation des sols., Tech. Rep. Rapport d'étape no 3, Identification des enjeux exposés aux crues et définition et analyse des casiers stratégiques, Territoire Rhône, 2003 (in French).

Tapia-Silva, F.-O., Itzerott, S., Foerster, S., Kuhlmann, B., and Kreibich, H.: Estimation of flood losses to agricultural crops using remote sensing, Phys. Chem. Earth, Parts A/B/C, 36, 253265, 2011.

Thieken, A. H., Ackermann, V., Elmer, F., Kreibich, H., Kuhlmann, B., Kunert, U., Maiwald, H., Merz, B., Müller, M., Piroth, K., Schwarz, J., Schwarze, R., Seifert, I., and Seifert, J.: Methods for the evaluation of direct and indirect flood losses, in: 4th International Symposium on Flood Defence: Managing Flood Risk, Reliability and Vulnerability Toronto, Ontario, Canada, 68 May, Institute fo Catastrophic Loss Reduction, Toronto, Ontario, Canada, 2008.

Torterotot, J.-P.: Le coût des dommages dus aux inondations: Estimation et analyse des incertitudes, Thèse de doctorat, spécialité sciences et techniques de l'environnement, École Nationale des Ponts et Chaussées, Paris, 1993 (in French).

Twining, S., Procter, C., Wilson, L., Frost, A., Phillips, K., Turner, T., Tiffin, D., Emery, J., Walker, O., Welch, S., and Wells, A.: Impacts of 2007 Summer Floods on Agriculture, Tech. Rep. Final, ADAS, Cambridge, UK, 2007.

USACE: AGDAM, Agricultural Flood Damage Analysis, User's Manual (Provisionnal), Computer Program Documentation CPD-48, US Army Corps of Engineers, Institute for Water Resources, Hydrologic Engineering Center (HEC), Davis, CA, 1985. 